\title{
ТРЕНДЫ НАЛОГООБЛОЖЕНИЯ ДОХОДОВ НАСЕЛЕНИЯ ПО БАНКОВСКИМ ВКЛАДАМ В СТРАНАХ СОЮЗНОГО ГОСУДАРСТВА
}

\author{
В.В. Иванов, Н.В. Покровская, О.А. Теляк*
}

Дана характеристика тенденций налогообложения доходов по банковским вкладам в странах Союзного государства, проведена оценка их предпосылок и последствий. Методология исследования основана на статистическом анализе развития банковских систем в целом и сбережений населения в банковских учреждениях в частности, обобщении подходов к налогообложению процентных доходов по розничным банковским вкладам. Показано, что финансово-банковские системы России и Беларуси достаточно близки в силу общих исторических, экономических и культурных истоков.

Ключевые слова: банковская система, сбережения, доход по банковскому вкладу, подоходный налог с физических лиц.

JEL-классификация: H24, G21, G28.

DOI: $10.46782 / 1818-4510-2021-2-70-80$

Материал поступил 19.04.2021 2.

Банковский сектор является основой финансовых систем стран Союзного государства. Вклады физических лиц - это один из самых значимых источников фондирования банков: их доля в совокупных пассивах банковского сектора на начало 2021 г. составила более одной трети в России и более двух третей в Беларуси. В периоды финансовой нестабильности значимость сбережений населения как источника фондирования банков для обеспечения устойчивости финансовой системы существенно возрастает как для экономики в целом, так и для устойчивости банковской системы в частности. Это полностью справедливо и в условиях введения в отношении крупнейших банков стран Союзного государства западных санкций, и в период коронакризиса.

С точки зрения экономической теории, вклады физических лиц являются формой частных сбережений и входят в нацио- нальные сбережения. Уровень национальных сбережений выступает важным фактором экономического процветания в долгосрочном периоде. Неудивительно, что анализ международной статистики показывает тесную связь уровня национальных сбережений и показателей экономического благосостояния (Иванов, Иевлева, Львова, Покровская, 2019), что определяет рост сбережений как один из основных факторов экономического роста (Масгрейв, Масгрейв, 2009).

На формирование и инвестирование фондов накопления населения оказывают влияние величина доходов домохозяйств и ряд факторов, отдельное место среди которых занимает подоходное налогообложение (Покровская, 2016). Опыт Беларуси по созданию режима налоговой поддержки долгосрочных банковских депозитов населения, с одной стороны, и реализуемая с 2021 г. реформа взимания НДФЛ по банковским вкладам в России, с другой, обус-

* Иванов Виктор Владимирович (viktor.ivanov@spbu.ru), доктор экономических наук, профессор, Санкт-Петербургский государственный университет (г. Санкт-Петербург, Россия);

Покровская Наталья Владимировна (n.pokrovskaia@spbu.ru), кандидат экономических наук, доцент, Санкт-Петербургский государственный университет (г. Санкт-Петербург, Россия);

Теляк Оксана Александровна (teliak.o@polessu.by), кандидат экономических наук, доцент, Полесский государственный университет (г. Пинск, Беларусь). 
ловили цель данного исследования: охарактеризовать тенденции налогообложения доходов по банковским вкладам в странах Союзного государства, а также оценить их предпосылки и последствия.

Методология исследования предполагает: сравнительный анализ банковских систем стран с разным уровнем финансового развития и соотношение их со странами Союзного государства; выделение схожих черт, а также специфики востребованности банковских услуг у населения России и Беларуси; подробную характеристику налогообложения доходов по розничным банковским депозитам в Республике Беларусь и его отражения на условиях привлечения средств банковскими посредниками; описание развития взимания налога на доходы физических лиц по банковским вкладам в Российской Федерации, раскрытие причин широкой дискуссии о реформировании этого налога в 2010-е годы и формулировку возможных последствий изменения порядка взимания НДФЛ с 2021 г. Эмпирической базой исследования стали оценки глобального финансового развития Всемирного банка, статистическая и фактологическая информация Национального банка Республики Беларусь, Министерства по налогам и сборам Беларуси, Центрального банка Российской Федерации, Министерства финансов и Федеральной налоговой службы России.

\section{Взаимосвязь налогообложения и сбережений населения}

Налогообложение доходов от сбережений в теории имеет два противоположных следствия: эффект замещения и эффект дохода. Повышение ставки налога на доходы, с одной стороны, снижает доходность после налогообложения и снижает стимулы сберегать (эффект замещения). С другой стороны, чем ниже доходность, тем больше нужно сберегать (эффект дохода), чтобы обеспечить себе необходимое потребление в будущем (Sandmo, 1985). Если эффекты замещения и дохода примерно равны, то сбережения безразличны к изменению налогов на доходы от сбережений. Ph. Opoku (2000) по результатам анализа взаимосвязи процентных ставок и норм сбережения девятнадцати стран ОЭСР с 1965 по 2018 г. показал, что при налогообложении доходов от сбережения в краткосрочной перспективе большее значение имеет эффект дохода, а в долгосрочной эффект замещения.

Среди основных вопросов архитектуры системы оптимального налогообложения особое место занимает дискуссия о нулевом обложении доходов с капитала. Несмотря на то, что в ряде теоретических моделей обосновывается желательность освобождения дохода от капитала от налогообложения, а доводы против освобождения слабо аргументированы (Mankiw, Weinzierl, Yagan, 2009), все же в налоговых системах большинства стран этот налог присутствует как для юридических, так и для физических лиц ${ }^{1}$ (Harding, 2013).

Система налогообложения отражается на доходности различных инструментов сбережения, оказывая влияние на финансовое поведение экономических субъектов. Порядок обложения налогом доходов вследствие различных направлений вложения средств может быть симметричным или, наоборот, создавать дополнительные налоговые преимущества для того или иного направления, искажать выбор физических лиц. Различия налоговых условий в зависимости от инструмента сбережения и статуса сберегателя являются отправной точкой ряда исследований и даже надгосударственных инициатив (Huizinga, Nicodeme, 2004). Влияние подоходного налога на выбор инструмента сбережения оценивается в работах (Alan, Atalay, Crossley, Jeon, 2010; Ochmann, 2014; Pokrovskaia, Belov, 2020). Однако, хотя вложения в банковские вклады популярны у населения в большинстве стран и при этом часто предполагаются специальные условия взимания подоходных налогов, эмпирические исследования последствий изменения подоходных налогов с процентов по банковским вкладам достаточно немногочисленны. Здесь следует отметить работу (Randelovic, 2016) о реформе подоходного налогообложения в Сербии. Эконометрические расчеты позволили автору сделать вывод, что повышение ставки налога с процентных доходов на 5 п. п. вызовет снижение банковских депозитов бо-

${ }^{1}$ OECD. 2018. Taxation of Household Savings. OECD Publishing, Paris. 
лее чем на 2,3\%. Оценка эластичности изменения вложений в различные виды сбережений в зависимости от уровня налогообложения представляет бесспорный интеpec. Вместе с тем все чаще при построении национальных моделей подоходного налогообложения используются налоговые способы поддержки желаемых видов сбережений, в том числе различных условий банковских вкладов.
Розничные депозиты в банковских системах стран Союзного государства

Финансовые системы стран Союзного государства достаточно близки в силу общих исторических, экономических и культурных истоков. Безусловно, масштабы финансовых и банковских систем стран различаются, их глубина разнится, однако некоторые качественные показатели достаточно близки. В табл. 1 представлены от-

Таблица 1

Масштабы привлечения средств в банковские вклады и иные параметры банковских систем в 2017 г.

\begin{tabular}{|c|c|c|c|c|}
\hline Страна & $\begin{array}{c}\text { Депозиты } \\
\text { по отношению } \\
\text { к ВВП, \% } \\
\end{array}$ & $\begin{array}{c}\text { Доля активов } \\
\text { банков в ВВП, } \\
\% \\
\end{array}$ & $\begin{array}{c}\text { Чистая процентная } \\
\text { банковская маржа, } \\
\%\end{array}$ & $\begin{array}{c}\text { Доля граждан в возрасте от } \\
15 \text { лет, имеющих } \\
\text { банковский счет, \% }\end{array}$ \\
\hline Люксембург & 399,7 & 109,1 & 1,1 & 98,8 \\
\hline Япония & 221,0 & 157,5 & 0,8 & 98,2 \\
\hline Швейцария & 171,3 & 176,3 & 0,8 & $\mathrm{H} /$ д \\
\hline Таиланд & 126,1 & 139,0 & 3,5 & 81,0 \\
\hline Корея & 123,8 & 141,5 & 2,0 & 94,9 \\
\hline Сингапур & 118,6 & 151,7 & 1,9 & 97,8 \\
\hline Нидерланды & 97,0 & 123,3 & 2,0 & 99,6 \\
\hline Испания & 96,8 & 129,9 & 3,1 & 93,8 \\
\hline Германия & 82,1 & 91,1 & 1,3 & 99,1 \\
\hline Австрия & 81,4 & 97,1 & 2,3 & 98,2 \\
\hline Франция & 81,4 & 113,0 & 1,3 & 94,0 \\
\hline Италия & 81,3 & 118,1 & 1,8 & 93,8 \\
\hline США & 80,8 & 62,4 & 3,4 & 93,1 \\
\hline Египет & 75,6 & 89,3 & 3,7 & 32,1 \\
\hline Чехия & 69,5 & 61,3 & 2,4 & 81,0 \\
\hline Швеция & 68,4 & 135,3 & 1,5 & 99,7 \\
\hline Болгария & 67,7 & 60,9 & 4,3 & 72,2 \\
\hline Финляндия & 66,9 & 100,3 & 1,6 & 99,8 \\
\hline Филиппины & 66,1 & 58,3 & 4,1 & 31,8 \\
\hline Индия & 64,9 & 68,4 & 3,0 & 79,8 \\
\hline Бразилия & 62,3 & 105,3 & 6,3 & 70,0 \\
\hline Норвегия & 61,6 & 134,4 & 2,0 & 99,7 \\
\hline Эстония & 59,2 & 67,4 & 4,2 & 98,0 \\
\hline ЮAP & 57,9 & 78,0 & 3,7 & 67,4 \\
\hline Дания & 56,3 & 172,3 & 1,2 & 99,9 \\
\hline Польша & 55,7 & 70,1 & 3,2 & 86,7 \\
\hline Китай & 54,7 & 174,5 & 2,3 & 80,2 \\
\hline Россия & 48,4 & 58,1 & 6,1 & 75,8 \\
\hline Турция & 46,0 & 72,9 & 4,5 & 67,7 \\
\hline Литва & 43,1 & 44,6 & 2,1 & 82,9 \\
\hline Казахстан & 32,3 & 30,1 & 4,6 & 58,7 \\
\hline Беларусь & 30,6 & 45,9 & 6,8 & 81,2 \\
\hline Украина & 28,1 & 46,4 & 6,2 & 62,9 \\
\hline Азербайджан & 21,9 & 27,9 & 6,1 & 28,6 \\
\hline $\begin{array}{l}\text { Кыргызская } \\
\text { Республика }\end{array}$ & 19,6 & 22,0 & 9,8 & 38,3 \\
\hline Таджикистан & 12,0 & 21,5 & 6,2 & $\mathrm{H} /$ д \\
\hline
\end{tabular}

Примечание. Данные по Швейцарии и Таджикистану приведены на 2016 г.

Источник. World Bank. Global financial development Database. October 2019 Version. URL: https:// www.worldbank.org/en/publication/gfdr/data/global-financial-development-database 
дельные характеристики банковских систем различных стран, оцениваемые Всемирным банком, данные отсортированы по отношению банковских депозитов к ВВП.

Объемы банковских депозитов связаны с уровнем развитости финансового рынка. В странах с развитым финансовым рынком (по классификации S\&P Dow Jones Indices) ${ }^{2}$ величина средств, привлекаемых кредитными организация во вклады, схожа с ВВП и даже превышает его. Несмотря на близкие значения соотношения банковских вкладов и ВВП в Таиланде и Kopee, Финляндии и Филиппинах, Дании и ЮАР, в среднем в странах с формирующимся рынком объемы привлечения средств на банковские депозиты ниже. Страны с развитыми рынками характеризуются также более высоким уровнем активов банковского сектора (они превышают ВВП в большинстве стран) и более низкой процентной банковской маржой. Уровень активов банковского сектора в России и Беларуси составляет 50-60\% ВВП; банковский спрэд находится на уровне $6-7 \%$; схожая и банковская концентрация (активы трех крупнейших банков в активах банковской системы) - 50-60\%. Охват населения банковскими услугами в Беларуси выше; депозиты в России в 2017 г. составляли около половины ВВП, в Беларуси - около трети ВВП.

${ }^{2}$ URL: https://www.spglobal.com/spdji/en/documents/ indexnews/announcements/20200819-1206359/1206359_spdji 2020countryclassificationconsultation8-19-2020.pdf
Депозиты физических лиц преобладают над депозитами юридических лиц и в Беларуси, и в России (табл. 2). Различия в структуре депозитов физических лиц по анализируемым странам проявляются в валюте, в которой население предпочитает хранить свои сбережения в банковских организациях. Если в России в среднем за 7 лет почти 77\% вкладов физических лиц привлекались в национальной валюте, то в Беларуси депозиты населения в национальной валюте составляли лишь немногим более $28 \%$ всех вкладов. Данное соотношение является наглядной иллюстрацией проблемы достаточно высокой долларизации (валютизации) экономики Беларуси, когда экономические агенты в попытке застраховать риски пытаются инвестировать в иностранную валюту.

В России преобладают вклады населения в национальной валюте, размещенные на срок от полугода до одного года (табл. 3). Наибольшей изменчивостью за семь лет отличалась доля депозитов в российских банковских организациях сроком до тридцати дней; при этом доля вкладов сроком от одного года до трех лет оставалась наиболее стабильной.

Сроки, которые предпочитали физические лица для размещения новых депозитов в Беларуси, более варьировались (табл. 4). Что касается динамики сроков банковских вкладов по годам, то самые существенные изменения имели место в 2016 и

Таблица 2

Депозиты физических лиц в банковских системах Беларуси и России

\begin{tabular}{|l|c|c|c|c|c|c|c|c|c|}
\hline \multicolumn{1}{|c|}{ Депозиты } & 2014 & 2015 & 2016 & 2017 & 2018 & 2019 & 2020 \\
\hline \multicolumn{8}{|c|}{ Республика Беларусь } \\
\hline $\begin{array}{l}\text { Всех секторов экономики } \\
\text { в банках, млрд бел. руб. }\end{array}$ & 213784 & 295207 & 29946 & 34796 & 37490 & 42303 & 42978 \\
\hline $\begin{array}{l}\text { Физических лиц в банках, } \\
\text { млрд бел. руб. }\end{array}$ & 134333 & 192720 & 19074 & 20104 & 22174 & 24019 & 22258 \\
\hline \multicolumn{7}{|c|}{ Российская Федерация } \\
\hline $\begin{array}{l}\text { Всех секторов экономики } \\
\text { в банках, млрд руб. }\end{array}$ & 42237 & 40585 & 43887 & 50112 & 52233 & 58125 & 42237 \\
\hline $\begin{array}{l}\text { Физических лиц в банках, } \\
\text { млрд руб. }\end{array}$ & 23219 & 24200 & 25987 & 28460 & 30549 & 32556 & 23219 \\
\hline
\end{tabular}

Примечание. Начиная с 2016 г., статистические данные по Республике Беларусь приведены с учетом деноминации 01.07.2016 г. бел. рубля. Данные за 2020 г. приведены на 01.12.2020 г. для Республики Беларусь и на 01.11.2020 г. для Российской Федерации.

Источник. Данные Национального банка Республики Беларусь и Центрального банка Российской Федерации. 
Структура банковских вкладов (депозитов) физических лиц в российских рублях в Российской Федерации в разрезе сроков привлечения, \%

\begin{tabular}{|c|c|c|c|c|c|c|c|}
\hline \multirow{2}{*}{ Период } & \multicolumn{9}{|c|}{ Срок привлечения } \\
\cline { 2 - 9 } & $\begin{array}{c}\text { До } \\
\text { востребования }\end{array}$ & $\begin{array}{c}\text { До 30 } \\
\text { дней }\end{array}$ & $\begin{array}{c}\text { От 31 } \\
\text { до 90 дней }\end{array}$ & $\begin{array}{c}\text { От 91 } \\
\text { до 180 дней }\end{array}$ & $\begin{array}{c}\text { От 181 дня } \\
\text { до 1 года }\end{array}$ & $\begin{array}{c}\text { От 1 года } \\
\text { до 3 лет }\end{array}$ & $\begin{array}{c}\text { Свыше } \\
3 \text { лет }\end{array}$ \\
\hline 2014 & 9,53 & 1,24 & 17,69 & 12,20 & 22,51 & 34,32 & 2,51 \\
\hline 2015 & 5,20 & 0,81 & 16,83 & 25,24 & 30,90 & 20,28 & 0,73 \\
\hline 2016 & 5,11 & 0,92 & 13,94 & 21,11 & 37,21 & 21,23 & 0,48 \\
\hline 2017 & 4,47 & 1,49 & 13,92 & 34,35 & 27,29 & 18,12 & 0,36 \\
\hline 2018 & 4,40 & 2,65 & 11,45 & 30,63 & 31,61 & 18,59 & 0,66 \\
\hline 2019 & 5,03 & 5,90 & 12,31 & 22,47 & 34,22 & 19,52 & 0,56 \\
\hline $\begin{array}{c}2020 \text { (январь- } \\
\text { ноябрь) }\end{array}$ & 5,71 & 5,45 & 10,90 & 18,42 & 41,92 & 16,91 & 0,69 \\
\hline
\end{tabular}

Источник. Данные Центрального банка Российской Федерации. URL: http://www.cbr.ru/statistics/ bank_sector/int_rat/

\section{Структура банковских вкладов (депозитов) физических лиц в белорусских рублях}

в Республике Беларусь в разрезе сроков привлечения, \%

\begin{tabular}{|c|c|c|c|c|c|c|c|}
\hline \multirow{2}{*}{ Период } & \multicolumn{9}{|c|}{ Срок привлечения } \\
\cline { 2 - 9 } & До востребования & $\begin{array}{c}\text { До 1 } \\
\text { месяца }\end{array}$ & $\begin{array}{c}1-3 \\
\text { месяца }\end{array}$ & $\begin{array}{c}3-6 \\
\text { месяцев }\end{array}$ & $\begin{array}{c}6-12 \\
\text { месяцев }\end{array}$ & 1-3 года & $\begin{array}{c}\text { Свыше } \\
3 \text { лет }\end{array}$ \\
\hline 2014 & 0,94 & 24,73 & 34,91 & 12,70 & 6,83 & 19,78 & 0,11 \\
\hline 2015 & 2,95 & 9,44 & 56,83 & 5,34 & 7,05 & 18,28 & 0,11 \\
\hline 2016 & 7,62 & 10,47 & 32,74 & 10,45 & 9,23 & 29,21 & 0,29 \\
\hline 2017 & 8,45 & 9,09 & 22,39 & 12,49 & 12,90 & 34,54 & 0,12 \\
\hline 2018 & 5,09 & 6,92 & 23,95 & 15,86 & 15,56 & 32,51 & 0,11 \\
\hline 2019 & 2,96 & 3,23 & 37,24 & 15,86 & 6,25 & 34,37 & 0,09 \\
\hline $\begin{array}{c}2020 \text { (январь- } \\
\text { сентябрь) }\end{array}$ & 3,88 & 0,61 & 44,85 & 17,37 & 4,31 & 26,88 & 2,1 \\
\hline
\end{tabular}

Источник. Данные Национального банка Республики Беларусь. URL: http:// https://www.nbrb.by/ publications/bulletin/stat_bulletin_2020_11.pdf

2020 гг. Тренды сбережения населения в 2020 г., в рамках влияния пандемии Covid19 на экономическую ситуацию и финансовое поведение, требуют специального исследования. Изменения 2016 г. связаны с ростом доли розничных вкладов, размещенных в белорусских банках на срок более одного года. Данная доля сохранилась с 2016 г. на уровне более 30\% всех депозитов физических лиц. Соответствующий показатель для России снизился до 22\% в 2015 г. и находится сегодня на среднем уровне порядка $20 \%$.

Изменения сроков депозитов населения в национальной валюте в странах Союзного государства в середине 2010-х годов напрямую связаны с налоговым регулированием доходов физических лиц от сбережений.

\section{Налогообложение доходов по банковским вкладам в Беларуси}

Закон Республики Беларусь от 21.12.1991 г. № 1327-XII «О подоходном налоге с физических лиц» предполагал освобождение от налога, взимаемого по прогрессивной ставке, доходов в виде процентов, полученных по банковским счетам, вкладам (депозитам) в банках, находящихся на территории Республики Беларусь. Важность формирования банковской системы страны обуславливала стремление налоговыми методами стимулировать население для размещения сбережений в банковских вкладах. И хотя значимость розничных депозитов в пассивах белорусских банков всегда была высокой, все же существовали исследования, что потенциал сбережений населения использован недостаточно (Плешкун, 2009). С 2010 г. 
взимание подходного налога регулируется Налоговым Кодексом Республики Беларусь, освобождение от налога процентных доходов по банковским вкладам было сохранено.

В середине 2010-х годов задачи и направления развития банковской системы Беларуси значимо отличались от таковых в 1990-е годы, что актуализировало необходимость включения процентных доходов населения в налоговую базу на фоне дискуссий о потенциале налогового регулирования банковской сферы (Стефанович, 2018). При этом сложности планирования деятельности банков были связаны с краткосрочностью депозитов населения (в 2015 г. около 80\% депозитов имели срок до 1 года - табл. 4), к тому же средства могли быть затребованы вкладчиками в любой момент.

С 1 апреля 2016 г. единая ставка подоходного налога в размере $13 \%$ стала распространяться на доходы по вкладам в белорусских банках, однако с учетом существенной оговорки. В соответствии с Декретом Президента Республики Беларусь № 7 от 11.11.2015 г. «О привлечении денежных средств во вклады (депозиты)», подоходным налогом облагаются только вклады в белорусских рублях, размещенные на срок менее одного года, и вклады в иностранной валюте сроком менее двух лет. Так на депозитном рынке был создан новый вид вклада - безотзывной, который, с одной стороны, стимулировался подоходным налогом, а с другой стороны - позволял формировать более стабильный и предсказуемый источник банковских пассивов (Кузюк, Куфто, 2020). С учетом корректив процентной ставки на подоходный налог (рис. 1), а также в связи с близостью реальной процентной ставки с учетом подоходного налога по вкладам сроком до одного года и прогнозируемого уровня инфляции в Республике Беларусь ${ }^{3}$, безотзывные вклады сроком более 1 года стали еще более конкурентоспособными.

Преференциальный режим налогообложения доходов по вкладам в национальной по сравнению с иностранной валютой отражает стремление стимулировать сбережения в белорусских рублях. Соотношение ставок с учетом подоходного налога для свободно конвертируемых валют, пожалуй, еще более показательно (рис. 2) - весной-летом 2017 г. ставка по безотзывным вкладам в СКВ на срок более 2 лет (освобождаемая от налогообложения) была несколько ниже номинальной ставки на срок от одного года до двух,

${ }^{3}$ Бусыгин Ю.Н., Яцына А.О. 2018. Расчет эффективной процентной ставки по банковским вкладам с учетом подоходного налога на процентный доход. Перспективы учета, анализа и налогообложения в странах - членах СНГ: материалы конференции. С. 35-37.

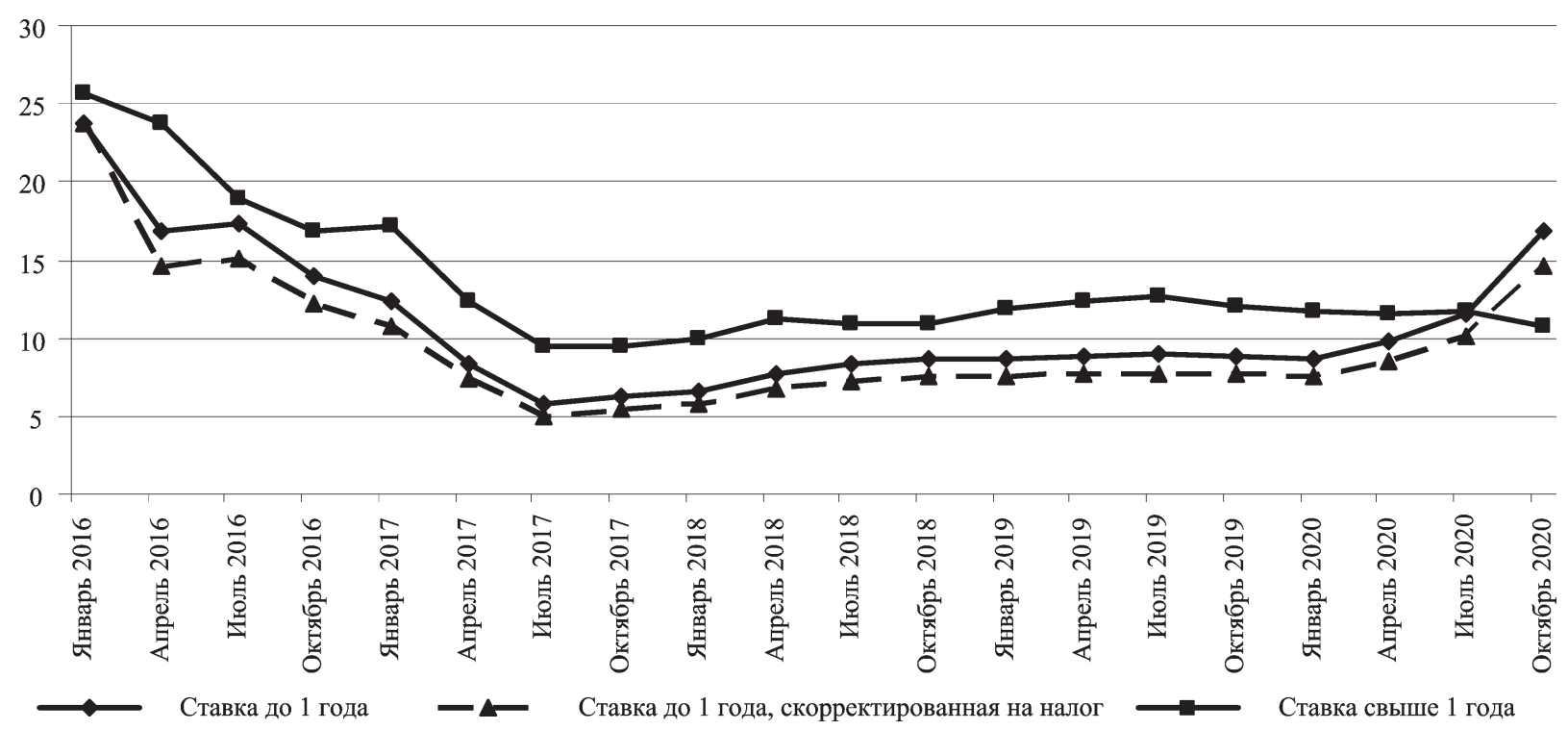

Рис. 1. Процентные ставки новых банковских вкладов (депозитов) физических лиц в белорусских банках в национальной валюте

Источник. Данные Статистического бюллетеня Национального банка Республики Беларусь. 


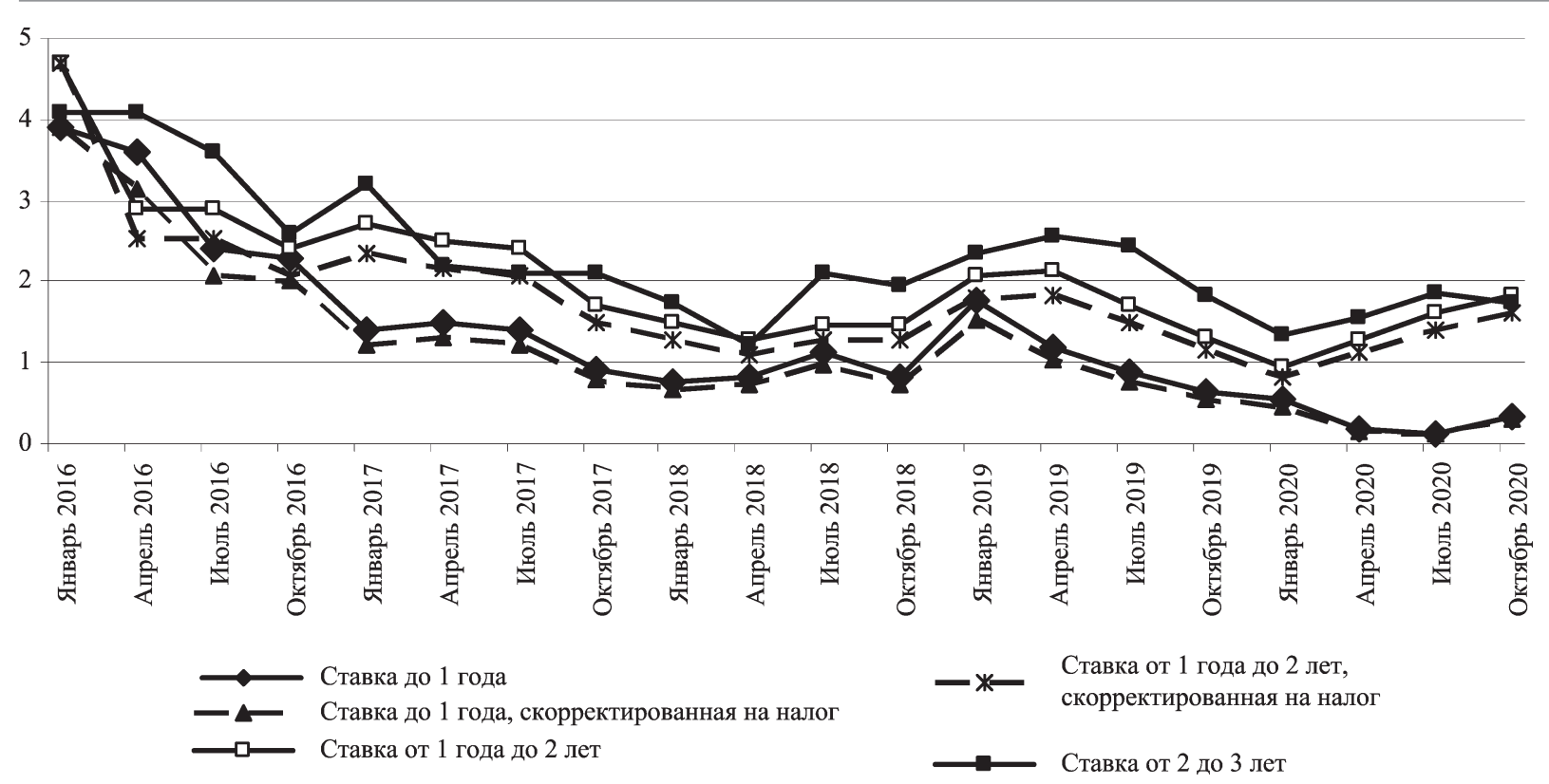

Рис. 2. Процентные ставки новых банковских вкладов (депозитов) физических лиц в белорусских банках в свободно конвертируемой валюте

Источник. Данные Статистического бюллетеня Национального банка Республики Беларусь.

однако с учетом подоходного налога это различие было нивелировано.

Взгляды на реформу налогообложения доходов по банковским вкладам в Беларуси различались: с одной стороны, ориентир на стабилизацию ресурсной базы коммерческих банков оценивался положительно (Горобец, 2016), с другой стороны, возникали опасения о снижении доверия населения к банковской системе, об оттоке их вкладов, а также о росте издержек банков на расчет и удержание налога в качестве налогового агента. Первые оценки нового порядка налогообложения процентных доходов были весьма сдержанными. В частности, на онлайн-конференции в марте 2016 г. отмечалось, что, судя по результатам проводимых опросов, нормы Декрета № 7 не оказывают существенного влияния на поведение вкладчиков по сравнению с такими факторами, как сезонность и снижение доходов ${ }^{4}$. Вместе с тем анализ данных о привлечении средств населения в банковские вклады Национального Банка Республики Беларусь по прошествии пяти лет (рис. 1) наглядно показывает, что основная цель введения налога на доходы по банковским вкладам была достигнута - зна-

${ }^{4}$ URL: http://www.nalog.gov.by/ru/confer/view/ nalogooblozhenie-doxodov-po-vkladam-21757// чимость депозитов, привлеченных на срок более одного года, значительно увеличилась с 2016 г. и к 2020 г. составила более трети всех банковских депозитов населения в национальной валюте. На наш взгляд, успешность налогового регулирования сберегательного поведения населения в Беларуси требует особого изучения и может стать примером для реализации в иных странах с транзитивной экономикой.

\section{Налогообложение доходов по банковским вкладам в России}

В СССР процентные доходы физических лиц по банковским вкладам не облагались налогом. Эта же норма действовала в российском налоговом законодательстве до 1997 г. Однако освобождение доходов по банковским вкладам в целях стимулирования сбережений населения на депозитах обернулось на практике схемой теневой безналоговой выплаты доходов. В частности, в рамках так называемой «банковской схемы» (Назаров, 2011) вместо выплаты заработной платы, которая облагается социальными взносами и подоходным налогом, доходы физическим лицам перечислялись в виде существенно завышенных процентов по банковским вкладам. Чаще всего данная схема использовалась банками для 
выплаты заработной платы своим сотрудникам или акционерам, а также обычными компаниями, заключившими с банками такую договоренность. Для пресечения данной схемы в 1997 г. был введен налог в размере $15 \%$ на процентные доходы физических лиц по банковским вкладам (в части превышения условий вклада ставки рефинансирования Центрального банка Российской Федерации).

С 2001 г. порядок налогообложения доходов по банковским вкладам физических лиц регулируется Налоговым кодексом Российской Федерации. В целях дальнейшей борьбы с серыми схемами выплаты доходов на фоне базовой ставки НДФЛ 13\% ставка налога для процентных доходов по банковским вкладам была повышена до 35\% и применялась только в части доходов по процентной ставке свыше определенного налогового ограничения. С 2001 по 2020 г. ставка НДФЛ оставалась прежней, зато довольно часто менялось налоговое ограничение.

В 2010-е годы обсуждалось несколько предложений по реформированию порядка налогообложения доходов населения по вкладам в банках. В частности, в Основных направлениях налоговой политики Российской Федерации на 2014 г. и на плановый период 2015 и 2016 гг. предлагались сразу два проекта совершенствования налога на доходы по вкладам физических лиц: 1) снижение налогового ограничения до ставки рефинансирования, увеличенной на 3 п. п. - по вкладам в рублях, а по вкладам в иностранной валюте - до 6\% годовых; 2) введение абсолютного размера предельной суммы освобождаемых от налога доходов по вкладам. Декларируемой Министерством финансов России целью данных проектов являлось повышение для физических лиц привлекательности вложений в ценные бумаги (путем ужесточения налогообложения доходов по банковским вкладам).

Первый проект осенью 2013 г. был внесен на рассмотрение в Государственную Думу Российской Федерации (налоговое ограничение по нему предполагалось в размере ставки рефинансирования Центрального банка России плюс 3 п. п. по рубле- вым вкладам и 7 п. п. по валютным). Однако потенциал регулирующей и фискальной значимости подобных налоговых изменений вызывает сомнения. Оценить его реальные результаты невозможно, так как законопроект не был принят. Второй проект задумывался как своеобразный налог на роскошь. Предполагалось, что ставка налога будет равна 13\%, а предельная сумма дохода по вкладам, освобождаемая от налога, составит 1 млн руб. В итоге с 2014 г. порядок взимания налога на доходы по банковским вкладам так и не был ужесточен.

В апреле 2020 г. Президентом Российской Федерации был подписан Федеральный закон № 102-Ф3, согласно которому с 2021 г. подлежат обложению НДФЛ по ставке 13\% процентные доходы по вкладам в российских банках в размере, превышающем проценты, рассчитанные как 1 млн руб., умноженный на ключевую ставку Центрального банка Российской Федерации, действующую на первое число налогового периода.

В объявлении о повышении налогообложения пассивных доходов населения в России Президент Российской Федерации увязывал данные изменения с малым числом налогоплательщиков («мера затронет порядка $1 \%$ вкладчиков») и фискально-социальными целями («все дополнительные поступления в бюджет предлагаю целевым образом направлять на финансирование мер поддержки семей с детьми, на помощь людям, столкнувшимся с безработицей или оказавшимся на больничном» ${ }^{5}$ ).

В соответствии с разъяснениями Федеральной налоговой службы России ${ }^{6}$, декларирование процентных доходов физическими лицами не предполагается. Информация о вкладах будет предоставляться банками в налоговые органы; исходя из этих данных будет формироваться сводное налоговое уведомление для уплаты налога. Налог на доходы физических лиц по банковским вкладам за 2021 г. должен быть уплачен до декабря 2022 г.

Новый формат налога на доходы по банковским вкладам в России по сути представ-

${ }^{5}$ Обращение Президента РФ к гражданам 25.02.2020 г. URL: http://kremlin.ru/events/president/news/63061

${ }^{6}$ Налоговая политика и практика: как будет рассчитываться налог на проценты по вкладам. URL: https:// www.nalog.ru/rn77/news/activities_fts/10007632/ 
ляет собой попытку реализовать налог на роскошь (Гонин, Монич, 2020) или начать переход от пропорционального налога на доходы физических лиц к прогрессивному (вторым шагом этого перехода стало повышение ставки НДФЛ до 15\% на доходы граждан более 5 млн руб. в год; эта ставка распространяется на совокупные доходы физических лиц, включая проценты и дивиденды). Мера в целом соответствует опыту развитых стран ${ }^{7}$, хотя и с национальной спецификой в виде сохранения учета уровня ключевой ставки Центрального банка Российской Федерации для целей расчета налога на доходы физических лиц. Однако вопрос, насколько этот опыт Швейцарии, Люксембурга, Бельгии, Германии адекватен для формирующегося финансового рынка России, тем более в период коронакризиса (см. подробнее (Погорлецкий, Покровская, 2021)), остается открытым. А вот негативные последствия для российского банковского сектора очевидны. По оценкам М.Ю. Матовникова (2015), в I квартале 2015 г. в российских банках открыто 2568 тыс. вкладов величиной более 1 млн руб., их владельцами были 1,284 млн чел., или 1\% от численности населения, однако величина этих вкладов 1\% населения равнялась половине всех вкладов в российских банках. Подобное же соотношение наблюдалось и в 2020 г. $-55,9 \%$ вкладов в I квартале имели сумму более 1 млн руб. ${ }^{8}$ Таким образом, реформа коснется малого числа физических лиц, однако большей половины всех банковских вкладов. Налогообложение доходов по банковским вкладам в России закладывает возможность дестабилизации банковской системы, ухудшения экономической ситуации и увеличения числа безработных вместо декларируемой цели поддержки социально незащищенных слоев населения.

Исходная позиция о необходимости освобождения от налогообложения процентных доходов по банковским вкладам в Рос-

${ }^{7}$ На 1 января 2021 г. ограничение на необлагаемые проценты (исходя из ключевой ставки $4,25 \%$ и среднего курса рубля 90 руб. за 1 евро) эквивалентно 472 евро.

8 Мониторинг застрахованных вкладов за первое полугодие 2020 года. URL: https://www.asv.org.ru/news/154605 сийской Федерации и Республике Беларусь в период становления банковской и финансовой систем стран совпадала. Реформирование порядка взимания налогов с этих доходов в странах Союзного государства произошло в 2016-2021 гг. Если в Республике Беларусь налогообложение доходов физических лиц по процентным доходам в банках носит выраженный регулирующий характер (стимулирование долгосрочных и безотзывных вкладов), результатом которого стал почти двукратный рост значимости долгосрочных вкладов, то целевые установки новой модели налогообложения доходов по банковским вкладам в российских банках не очевидны. С одной стороны, признается, что новый порядок должен затронуть небольшой сегмент вкладчиков, т. е. фискальные перспективы налога ограничены. Однако и направление регулирующего воздействия не вполне понятно.

Процесс нахождения наилучшей модели налогообложения доходов от сбережения населения в России не завершен. Успешный опыт налогового регулирования банковской сферы Республики Беларусь имеет значимый потенциал для реализации в фискальной системе России.

Преимуществом российского налога на доходы по банковским вкладам образца 2021 г. является освобождение от обложения вкладов до 1 млн руб., что соответствует задаче снижения уровня бедности. Мы предлагаем дополнительно освободить от налогообложения доходы по банковским вкладам, размещенным в российских банках на срок не менее одного года; распространить это освобождение достаточно только на вклады в национальной валюте. В этом случае стабильность источников банков будет не только сохранена, но и преумножена за счет увеличения доли банковских вкладов на срок не менее одного года с целью снижения налоговых обязательств.

\section{СПИСОК ЛИТЕРАТУРЫ (REFERENCES)}

Гонин В.Н., Монич И.П. 2020. Исследование влияния доходов бюджета Российской Федерации от изменения Налогового кодекса в части налого- 
обложения доходов граждан. Вестник Забайкальского государственного университета. Т. 26. № 5. C. 75-82. [Gonin V.N., Monich I.P. 2020. The study of the impact on the Russian Federation budget revenues from the citizens' income taxation changes. Vestnik Zabaykal'skogo gosudarstvennogo universiteta. Vol. 26. No 5. PP. 75-82. (In Russ.)]

Горобец П.Д. 2016. Управление рублевыми и валютными сбережениями физических лиц в современных условиях. Труды Белорусского государственного технического университета. № 7. С. 4954. [Gorobets P.D. 2016. Managing ruble and foreign exchange savings of individuals in modern conditions. Trudy Belorusskogo gosudarstvennogo tehnicheskogo universiteta. No 7. PP. 49-54. (In Russ.)]

Иванов В.В., Иевлева А.Ю., Львова Н.А., Покровская Н.В. 2019. Национальные модели финансового благосостояния. Финансы и бизнес. № 1. C. 16-32. [Ivanov V.V., Ievleva A.Yu., Lvova N.A., Pokrovskaia N.V. 2019. National models of financial wealth. Finansy i biznes. No 1. PP. 16-32. (In Russ.)]

Кузюк И., Куфто В. 2020. Эконометрическое моделирование депозитов населения Беларуси. Банковский вестник. № 4. С. 60-68. [Kuzyuk I., Kufto V. 2020. Econometric modeling of deposits of the population of Belarus. Bankorskiy vestnik. No 4. PP. 60-68. (In Russ.)]

Масгрейв Р.А., Масгрейв П.Б. 2009. Государственные финансы: теория и практика. Москва: Бизнес Атлас. [Musgrave R.A., Musgrave P.B. 2009. Public finance: Theory and practice. Moscow: Biznes Atlas. (In Russ.)]

Матовников М.Ю. 2015. Сберегательная активность населения России. Деньги и кредит. № 9. C. 34-39. [Matovnikov M.Yu. 2015. Savings activity of the population of Russia. Den'gi $i$ kredit. No 9. PP. 34-39. (In Russ.)]

Назаров B.C. 2011. Налоговая система России в 1991-2008 годах. История новой России. Очерки, интервъю. Т. 1. СПб.: Норма. С. 449516. [Nazarov V. 2011. The tax system of Russia in 1991-2008. Istoriya novoy Rossii. Ocherki, interv'yu. Vol. 1. SPb.: Norma. PP. 449-516. (In Russ.)]

Плешкун А.M. 2009. Анализ сбережений населения Республики Беларусь. Вестник Белорусского государственного экономического университеma. № 1. C. 62-67. [Pleshkun A.M. 2009. Analysis of savings of the population of the Republic of Belarus. Vestnik Belorusskogo gosudarstvennogo ekonomicheskogo universiteta. No 1. PP. 62-67. (In Russ.)]

Погорлецкий А.И., Покровская Н.В. 2021. Сравнительный анализ мер фискального регулирования стран G20 в эпоху коронакризиса и в посткоронавирусной перспективе. Journal of Applied Economic Research. T. 20. № 1. C. 31-61. [Pogorletskiy A.I., Pokrovskaia N.V. 2021. Comparative Analysis of Fiscal Regulation Measures of the G20 Countries in the Era of the Coronavirus Crisis and in the Post-Coronavirus Perspective. Journal of Applied Economic Research. Vol. 20. No 1. PP. 31-61. (In Russ.)]

Покровская Н. В. 2016. Модели налогообложения доходов по банковским вкладам и их связь с объемами сбережения населения. Научный журнал НИУ ИТМО. Серия: Экономика и экологический менеджмент. № 3. С. 57-64. [Pokrovskaia N.V. 2016. Models of taxation of income from bank deposits and their relation with the volume of household savings. Nauchnyy zhurnal NIU ITMO. Seriya: Ekonomika $i$ ekologicheskiy menedzhment. No 3. PP. 57-64. (In Russ.)]

Стефанович Л.И. 2018. Налогообложение и банки: оценка состояния налога на прибыль. Банкаўскі веснік. № 5. C. 32-36. [Stefanovich L.I. 2018. Taxation and banks: assessment of the state of income tax. Bankaweski vesnik. No 5. PP. 32-36. (In Russ.)]

Alan S., Atalay K., Crossley Th., Jeon S. 2010. New evidence on taxes and portfolio choice. Journal of Public Economics. Vol. 94. Iss. 11-12. PP. 813-823.

Harding M. 2013. Taxation of Dividend, Interest, and Capital Gain Income. OECD Taxation Working Papers. No 19. Paris: OECD Publishing.

Huizinga H., Nicodeme G. 2004. Are international deposits tax-driven? Journal of Public Economics. Vol. 88. Iss. 6. PP. 1093-1118.

Mankiw G., Weinzierl M., Yagan D. 2009. Optimal taxation in theory and practice. Journal of Economic Perspectives. No 23. PP. 147-74.

Ochmann R. 2014. Differential income taxation and household asset allocation. Applied Economics. Vol. 46. Iss. 8. PP. 880-894.

Opoku Ph. 2020. The Short-Run and LongRun Determinants of Household Saving: Evidence from OECD Economies. Comparative Economic Studies. Vol. 62. Iss. 3. No 5. PP. 430-464.

Pokrovskaia N.V., Belov A.V. 2020.Tax revenues of local budgets in unitary states: A case study of Japan. Journal of Tax Reform. Vol. 6. No 1. PP. 73-89.

Randelovic S. 2016. Estimating the Impact of Income Tax on Personal Savings in Serbia: The Two Channels Approach. Acta Oeconomica. No 66. PP. 261-281.

Sandmo A. 1985. The effects of taxation on savings and risk taking. Handbook of Public Economics. Vol. 1. PP. 265-311. 
In citation: Belorusskiy Ekonomicheskiy zhurnal. 2021. No 2. PP. 70-80.

Belarusian Economic Journal. 2021. No 2. PP. 70-80.

\title{
TRENDS IN INDIVIDUAL TAXATION ON DEPOSITS IN RUSSIA AND BELARUS
}

\author{
Viktor Ivanov ${ }^{1}$, Natalia Pokrovskaia $^{1}$, Oksana Teliak $^{2}$ \\ Author affiliation: ${ }^{1}$ St. Petersburg University (St. Petersburg, Russia). \\ ${ }^{2}$ Polessky State University (Pinsk, Belarus). \\ Corresponding author: Viktor Ivanov (viktor.ivanov@spbu.ru).
}

\begin{abstract}
The article describes trends in individual taxation on deposits in Russia and Belarus. It also presents an assessment of its preconditions and possible outcomes. Methodology of the study is based on a statistical analysis of banking system development as a whole and as particular on household savings in banks. Approaches to taxation of interest income from retail bank deposits are generalized. Similarities between financial and banking systems in Russia and Belarus are illustrated due to common historical, economic and cultural background.
\end{abstract}

KEYWORDS: banking system, savings, income from a bank deposit, personal income tax.

JEL-code: H24, G21, G28.

DOI: $10.46782 / 1818-4510-2021-2-70-80$

Received 19.04.2021 